\title{
Occurrence of Branchiobdellida (Annelida : Clitellata) on freshwater crayfish in Croatia
}

\author{
G.I.V. Klobučar ${ }^{*}$, I. Maguire ${ }^{1}$, S. Gottstein ${ }^{1}$, S. R. Gelder ${ }^{2}$
}

${ }^{1}$ Department of Zoology, Faculty of Science, University of Zagreb, Rooseveltov trg 6, 10000 Zagreb, Croatia
${ }^{2}$ Department of Science and Math, University of Maine at Presque Isle, 181 Maine Street, Maine 04769, USA

There is very little information on the genus Branchiobdella and the species relationships with their freshwater crayfish hosts in Croatia. Therefore, a base-line study was needed so that future changes in available habitat brought about by urban development and the probable introduction of non-native species can be accurately assessed. This investigation used preserved freshwater crayfish collected from across Croatia between 1995 and 2005 as its source of the ectosymbionts. Crayfish species included Astacus astacus, A. leptodactylus, Austropotamobius pallipes, A. torrentium, and the allochtonous North American species, Orconectes limosus. Only native European species of branchiobdellids were found: Branchiobdella astaci, B. parasita, B. pentodonta, $B$. hexodonta, $B$. italica, and B. balcanica, and this is the first report on the occurrence of these species, apart from $B$. italica, in Croatia. The distribution of these branchiobdellidans is compared with climatic and river drainage systems, and literature reports of populations in other countries in the region.

Keywords: Branchiobdellidans, distribution, epibionts, freshwater crayfish, Croatia.

\section{Introduction}

Branchiobdellidans are ectosymbiotic clitellate annelids living primarily on freshwater astacoidean crayfish (Brinkhurst \& Gelder 2001). They have a Holarctic distribution with those in the Palaearctic realm forming two disjunct regions, one in East Asia and the other in Europe (Gelder et al. 1999). Although members of the genus Branchiobdella Odier, 1823 have been found in both of these regions, individual species are endemic and restricted to either East Asia (Gelder \& Ohtaka 2002) or Europe (Karaman 1970).

The taxonomy of the Branchiobdella in Europe according to Gelder (1996) consists of: Branchiobdella astaci Odier, 1823, B. parasita Henle, 1835, B. pentodonta Whitman, 1882, B. hexodonta Grüber, 1883, B. italica Canegallo, 1928, B. balcanica Moszyńsky, 1938, and B. kozarovi Subchev, 1978, with the status of the subspecies B. balcanica sketi Karaman, 1970 being debatable. Pop (1965) considered B. pentodonta, B. italica, and $B$.orientalis Pop, 1965 to form a subspecies complex of Branchiobdella pentodonta or the so-called pentodonta group (Karaman 1970). Karaman (1970) rein-

\footnotetext{
* Corresponding author : E-mail : gklobuca@ zg.biol.pmf.hr
}

stated the name balcanica due to its seniority over Pop's (1965) proposed orientalis. At the higher taxonomic level we have followed the common naming convention used in Brinkhurst and Gelder (2001) that uses branchiobdellidan for the order Branchiobdellida.

Major reviews of the distribution of branchiobdellidans in Europe are found in Pop (1965), and Karaman (1967, 1970), and, for south eastern Europe more detailed distributional information does exists for Hungary (Subchev 1984), Bulgaria (Subchev \& Stanimirova 1997), Slovenia, Croatia, Bosnia and Herzegovina, Macedonia (Karaman 1967, 1970), Serbia (Moszyński 1938, Karaman 1967), Slovakia (Halgoš 1972), Northern Italy (Gelder et al. 1994, Gelder et al. 1999, Oberkofler et al. 2002), Austria (Nesemann 1994), and southern Germany (Vogt 1999). Information on the presence of branchiobdellidans in Croatia is restricted to the study by Karaman (1967, 1970), which only reported B. italica from the Adriatic coast region. Georgevitch (1957) identified some specimens from the River Cetina in the same region of Croatia. His identifications were shown to be incorrect following a re-examination of Georgevitch's collection by Pop (1965). Although Pop found that all of the specimens in Georgevitch's collection were of existing species of Branchiobdella and there were no new spe- 
cies as claimed by Georgevitch, the lack of collection site and other information requires that this study be excluded from any modern surveys.

Reports on the distribution of crayfish in Croatia were summarized by Maguire and Gottstein-Matočec (2004). Austropotamobius pallipes (Lereboullet, 1858) were noted along the Adriatic coastal region, from Istra to the northern borders of Montenegro, while Austropotamobius torrentium (Schrank, 1803) and Astacus astacus (Linnaeus, 1758) were common inland in the Sava and Drava River drainages, with the higher altitude water bodies being favoured by A. torrentium. Austropotamobius torrentium as well as A. astacus were also found at a few locations along the Adriatic coast (Maguire et al. 2006) but these records are most probably the result of introductions made by local inhabitants. The eastern European Astacus leptodactylus (Eschscholz, 1823) was found in the Sava drainage (Maguire \& GottsteinMatočec 2004) and is progressing slowly westwards where it has almost reached neighbouring Slovenia (Maguire et al. 2006). Maguire \& Gottstein-Matočec (2004) recorded only one introduced North American species, Orconectes limosus (Rafinesque, 1817) in the country. Commercial introductions of non-native, North American crayfishes into Europe started about 150 years ago, but significantly increased in the number of species and quantity starting in 1960 (Holdich et al. 1999, Lewis 2002). Along with these crayfishes came some of their pathogens (Vogt 1999, Evans \& Edgerton 2002) and particularly the ectosymbiotic branchiobdellidans (Franzén 1962, Gelder et al. 1999, Quaglio et al. 2002, Gelder 2004).

The only available information on the distribution of branchiobdellidans in Croatia is almost 40 years old and is restricted to the southern parts of the country (Karaman 1967). More detailed reliable information on species diversity in Croatia is essential for balancing correctly the protection of fragile habitats while optimizing economic development. This survey was designed to collate the available information and material to assess the present state of branchiobdellidan/crayfish associations in Croatia. It forms a necessary prelude towards developing a balanced economic strategy, and to accurately assess the detrimental effects that imported North American crayfish and their allochtonous epifauna, will have on the national endemic species.

\section{Material and methods}

Our collection of crayfish from Croatia was made between 1995 and 2005 with specimens being preserved in various concentrations of ethanol or $10 \%$ formalin.
Crayfish, and the debris from their containers, were examined under a dissection microscope and any branchiobdellidans were removed and placed in vials with $70 \%$ ethanol for storage. The number of branchiobdellidans found per crayfish varied (from 1 to more than 200). Specimens selected for identification were dehydrated in a graded ethanol solution series, cleared in methyl salicylate, infiltrated with Canada balsam, mounted on slides under a cover glass (Gelder et al. 1994, 1999) and identified using Karaman (1967) and Gelder et al. (1994).

\section{Results}

An analysis of 315 crayfish from 80 Croatian populations resulted in branchiobdellidans being found in 47 of the populations (Table 1). Thirteen out of 19 examined populations (68.4\%) of A. astacus was found carrying branchiobdellidans, 23 out of 32 populations $(71.9 \%)$ of A. torrentium, and 11 out of 19 populations (57.9\%) of $A$. pallipes. The number of crayfish in each population varied from 1 to 21 individuals. The following branchiobdellidan species were identified: Branchiobdella parasita, B. pentodonta, B. balcanica, B. hexodonta, $B$. astaci, and $B$. italica. The distribution of these species on their crayfish hosts is given in Fig. 1 (for A. astacus), Fig. 2 (for A. torrentium) and Fig. 3 (for A. pallipes). Also, no branchiobdellidans were found on any of the seven populations of A. leptodactylus or on the three populations of $O$. limosus examined.

The species associations of branchiobdellidans and crayfishes are given in Table 2. Coexistence of two or more species of Branchiobdella on crayfish at the same location is presented in Table 3.

\section{Discussion}

This research has revealed the existence of a rich branchiobdellidan fauna living on freshwater crayfish in Croatia. Apart from the report of B. italica occurring in the waters of Adriatic drainage, namely: River Jadro, Rijeka konavljanska and Vrhovine near Knin (Karaman 1967), this is the first report of B. parasita, B. pentodonta, $B$. balcanica, B. hexodonta and B. astaci in Croatia. These findings were not unexpected given the diversity of Croatian astacofauna and the reports of the branchiobdellidan fauna in surrounding countries. According to Karaman (1967), B. parasita, B. hexodonta, B. pentodonta and $B$. balcanica (together with $B$. balcanica sketi) are present in Slovenia, Serbia, Bosnia and Herzegovina (excluding B. balcanica) and Macedonia. These four species have also been found in Slovakia (Halgoč 
Table 1. Distribution of Branchiobdellid species in Croatia $(\mathrm{P}=$ population number, $A a=A$. astacus, Al = Astacus leptodactylus, Ap $=$ Austropotamobius pallipes, $A t=$ Austropotamobius torrentium, $\mathrm{Ol}=$ Orconectes limosus, N.F. $=$ not found, N.I. $=$ not identified, UTM $=$ The Universal Tranverse Mercator coordinate system).

\begin{tabular}{|c|c|c|c|c|}
\hline $\mathbf{P}$ & $\begin{array}{l}\text { Crayfish } \\
\text { species }\end{array}$ & Waterbody - Site & $\begin{array}{c}\text { UTM } \\
10 \times 10 \mathrm{~km}\end{array}$ & Branchiobdellid species \\
\hline 1 & $A a$ & Borovik lake (Borovik, Našice) & BR 72 & N.F. \\
\hline 2 & $A a$ & Stream in Vladislavci (near Osijek) & CR 03 & N.F. \\
\hline 3 & $A a$ & Pazinčica (Grande, Pazin) & VL 10,11 & N.F. \\
\hline 4 & $A a$ & Borutski stream (Dausi, Pazin) & VL 21 & B. astaci \\
\hline 5 & $A a$ & Lokve lake (Lokve, Delnice) & VL 72 & B. pentodonta, B. balcanica \\
\hline 6 & $A a$ & Velika Paklenica (NP Paklenica, Starigrad) & WK 30 & N.F. \\
\hline 7 & $A a$ & Plitvice Lakes (NP Plitvice) & WK 46,47 & N.F. \\
\hline 8 & $A a$ & Korana (NP Plitvice) & WK 47 & N.F. \\
\hline 9 & $A a$ & Crno jezero, gravel pit (Velika Gorica) & WL 86 & B. parasita, B. balcanica \\
\hline 10 & $A a$ & Ježevo, gravel pit (Velika Gorica) & WL 86 & B. parasita \\
\hline 11 & $A a$ & Krapina (Konjščina) & WM 90 & $\begin{array}{l}\text { B. parasita, B. balcanica, } \\
\text { B. hexodonta }\end{array}$ \\
\hline 12 & $A a$ & Lonja (Podrute, Novi Marof) & $\begin{array}{l}\text { WM 90, } \\
\text { XM } 00\end{array}$ & B. balcanica \\
\hline 13 & $A a$ & Krapinčica (Kamena Gorica, Novi Marof) & WM 91 & N.I. \\
\hline 14 & $A a$ & Subocka (NP Lonjsko polje) & XL 32 & B. parasita \\
\hline 15 & $A a$ & Rajčevica Maslenjačka (Daruvar) & XL 75 & B. parasita \\
\hline 16 & $A a$ & Orljava (Kamenski Vučjak, Požega) & XL 94 & B. parasita, B. pentodonta \\
\hline 17 & $A a$ & Bednja (Novi Marof) & XM 01 & B. parasita, B. pentodonta \\
\hline 18 & $A a$ & Ljubelj (Varaždinske Toplice) & XM 01 & B. parasita \\
\hline 19 & $A a$ & Slugovina (Beletinec, Novi Marof) & XM 01 & B. parasita \\
\hline 1 & $A l$ & Sava (Slavonski Brod) & BR 60 & N.F. \\
\hline 2 & $A l$ & Drava (Osijek) & CR 14 & N.F. \\
\hline 3 & $A l$ & Mrežnica (Duga Resa) & WK 33 & N.F. \\
\hline 4 & $A l$ & Kupa (Letovanić) & WL 93 & N.F. \\
\hline 5 & $A l$ & Sava (NP Lonjsko polje, Jasenovac) & XL 32 & N.F. \\
\hline 6 & $A l$ & Sava (NP Lonjsko polje, Trebež) & XL 42 & N.F. \\
\hline 7 & $A l$ & Drava (Čingi Lingi, Molve) & XM 41 & N.F. \\
\hline 1 & $A p$ & Ljuta (Konavle) & BN 71, 81 & B. hexodonta \\
\hline 2 & $A p$ & Source Gradole (Brdo, Buje) & UL 92 & B. italica, B. astaci \\
\hline 3 & $A p$ & Vransko Lake (Cres) & VK 56 & B. astaci \\
\hline 4 & $A p$ & Mirna (Motovun) & VL 02 & B. italica, B. astaci \\
\hline 5 & $A p$ & Mirna (Buzet) & VL 12 & B. italica \\
\hline 6 & $A p$ & Butoniga (Motovun) & VL 12 & B. italica, B. astaci \\
\hline 7 & $A p$ & Račice (Račice, Buzet) & VL 22 & B. astaci \\
\hline 8 & $A p$ & Rječina (Rijeka) & VL 52 & N.F. \\
\hline 9 & $A p$ & Lake Bajer (Fužine) & VL 71 & N.F. \\
\hline 10 & $A p$ & Vransko Lake (Biograd) & WJ 46 & N.F. \\
\hline 11 & $A p$ & Zrmanja (Ogari, Obrovac) & WJ 69 & N.F. \\
\hline 12 & $A p$ & Roški falls (NP Krka, Šibenik) & WJ 76 & N.F. \\
\hline 13 & $A p$ & Source Bakovac (Gornji Kosinj, Gospić) & WK 15 & B. italica \\
\hline 14 & $A p$ & Matica (Vrgorac) & XH 98 & N.F. \\
\hline 15 & $A p$ & Source Jezero (Glavice, Sinj) & XJ 34 & N.F. \\
\hline
\end{tabular}


Table 1. Continued.

\begin{tabular}{|c|c|c|c|c|}
\hline $\mathbf{P}$ & $\begin{array}{l}\text { Crayfish } \\
\text { species }\end{array}$ & Waterbody - Site & $\begin{array}{c}\text { UTM } \\
10 \times 10 \mathrm{~km}\end{array}$ & Branchiobdellid species \\
\hline 16 & $A p$ & Badnjevice (Donji Proložac, Imotski) & XJ 71 & B. italica \\
\hline 17 & $A p$ & Prološko blato lake (D. Proložac, Imotski) & XJ 71 & B. italica \\
\hline 18 & $A p$ & Vrljika (Imotski) & XJ 71 & N.F. \\
\hline 19 & $A p$ & Modro oko (Komin, Neretva delta) & YH 07 & B. italica \\
\hline 1 & At & Stream Križ (Homer, Delnice) & VL 72 & B. parasita \\
\hline 2 & At & Unnamed stream (entrance of NP Risnjak) & VL 72 & B. parasita, B. pentodonta \\
\hline 3 & At & Unnamed stream (Crni lug, Delnice) & VL 72,73 & B. parasita, B. pentodonta \\
\hline 4 & At & Gerovica (Gerovo, Čabar) & VL 73,74 & N.I. \\
\hline 5 & At & Unnamed strem (Zalesina, Kupjak) & VL 92 & B. pentodonta \\
\hline 6 & At & Kobilica (Knin) & WJ 98 & B. parasita \\
\hline 7 & At & Sušik-sinkhole (Drežnica, Brinje) & WK 09 & B. parasita \\
\hline 8 & At & Sinkhole (Gornji Kremen, Slunj) & WK 49 & N.F. \\
\hline 9 & At & $\begin{array}{l}\text { Plitvice lakes (NP Plitvice, Čuića krčevine, } \\
\text { Korenica) }\end{array}$ & WK 56 & $\begin{array}{l}\text { B. parasita, } B \text {. pentodonta, } B \text {. } \\
\text { hexodonta }\end{array}$ \\
\hline 10 & At & Rječica (NP Plitvice, Korenica) & WK 56 & B. pentodonta \\
\hline 11 & At & Tounjčica (Tounj) & WL 21 & $\begin{array}{l}\text { B. pentodonta, } \\
\text { B. hexodonta }\end{array}$ \\
\hline 12 & At & Suvaja (Sošice, Ozalj) & WL 26 & B. pentodonta \\
\hline 13 & At & $\begin{array}{l}\text { Unnamed strem (Mrzlo Polje Žumberačko, } \\
\text { Samobor) }\end{array}$ & WL 37 & B. parasita \\
\hline 14 & At & Bregana (Kostanjevec Podvrški, Samobor) & WL 47 & $\begin{array}{l}\text { B. parasita, } B \text {. pentodonta, } B \\
\text { hexodonta }\end{array}$ \\
\hline 15 & At & Dubravica (Pušća, Zaprešić) & WL 58 & B. parasita, $B$. hexodonta \\
\hline 16 & At & Dolje stream (Podsused, Zagreb) & WL 67 & N.F. \\
\hline 17 & At & Veternica (PP Medvednica, Zagreb) & WL 67 & N.F. \\
\hline 18 & At & Sarni stream (PP Medvednica, Zagreb) & WL 68 & B. pentodonta \\
\hline 19 & At & Kraljevec (PP Medvednica, Zagreb) & WL 77 & B. parasita \\
\hline 20 & At & Bliznec (PP Medvednica, Zagreb) & WL 77 & B. parasita, B. pentodonta \\
\hline 21 & At & Mrzlak (PP Medvednica, Zagreb) & WL 77 & B. pentodonta \\
\hline 22 & At & Veliki potok (Lukšići, Zagreb) & WL 77 & N.F. \\
\hline 23 & At & Unnamed stream (PP Medvednica, Zagreb) & WL 77 & B. parasita, B. pentodonta \\
\hline 24 & At & Gračanski stream (PP Medvednica, Zagreb) & WL 77 & N.F. \\
\hline 25 & At & Srnec (PP Medvednica, Zagreb) & WL 78 & N.F. \\
\hline 26 & At & Bliznec (PP Medvednica, Zagreb) & WL 78 & B. parasita, B. pentodonta \\
\hline 27 & At & Željeznica (Ivanečka Željeznica, Ivanec) & WM 81, 91 & B. pentodonta \\
\hline 28 & At & Unnamed stream (Butižnica, Knin) & XJ 08 & B. pentodonta \\
\hline 29 & At & Source Jezero (Glavice, Sinj) & XJ 34 & N.F. \\
\hline 30 & At & Vrljika (Imotski) & XJ 71 & N.F. \\
\hline 31 & At & Lonja (Paka, Podrute) & XM 00, 01 & B. parasita, B. pentodonta \\
\hline 32 & At & Veličanka (near quarry Vidovići, Požega) & YL 03 & N.F. \\
\hline 1 & $\mathrm{Ol}$ & Dunav (Aljmaš) & CR 34 & N.F. \\
\hline 2 & $\mathrm{Ol}$ & Kopački rit (PP Kopački rit, Osijek) & CR 35 & N.F. \\
\hline 3 & $\mathrm{Ol}$ & Dunav (Batina) & CR 38 & N.F. \\
\hline
\end{tabular}




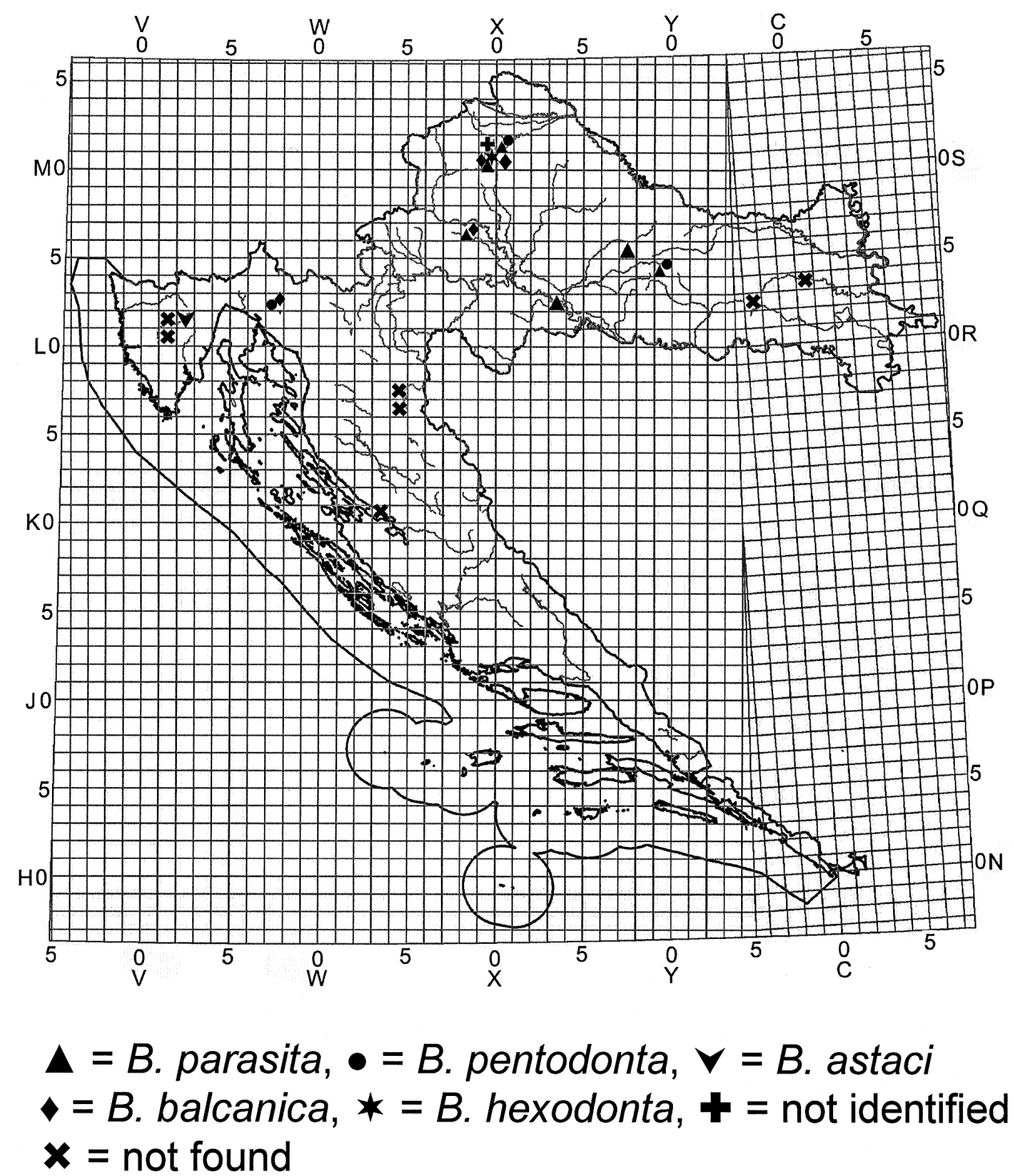

Fig. 1. The distribution of different branchiobdellidan species on Astacus astacus in Croatia.

1972), Austria (Nesemann 1994), and together with $B$. astaci, in Hungary and Bulgaria (Subchev 1984, Subchev \& Stanimirova 1997). Bulgaria also appears to be the western limit of B. kozarovi (Subchev 1978, Subchev \& Stanimirova 1997). In Northern Italy there have been reports of B. italica, B. hexodonta, B. parasita, B. astaci (Gelder et al. 1994, Gelder et al. 1999, Oberkofler et al. 2002) and the introduced North American species, Xironogiton victoriensis (Quaglio et al. 2002) and Cambarincola mesochoreus (Gelder et al. 1999).

The presence of $B$. parasita on the host's exoskeleton was noted only on A. astacus and A. torrentium. Both crayfish species are native to Croatia and inhabit the continental, relatively colder water bodies of the Black Sea drainage. Branchiobdella parasita was found on almost $50 \%$ of the examined populations of these species, and in the case of $A$. astacus it was by far the most frequently collected branchiobdellidan (Table 2). When B. parasita and $B$. pentodonta were both found on $A$. torrentium in Croatia, the frequency of $B$. parasita was always slightly lower than that of the latter (Table 2). These findings are similar to those reported from Bulgaria (Subchev \& Stanimirova 1997), where approximately $53 \%$ of $A$. astacus and $73 \%$ of $A$. torrentium populations contained B. par- 


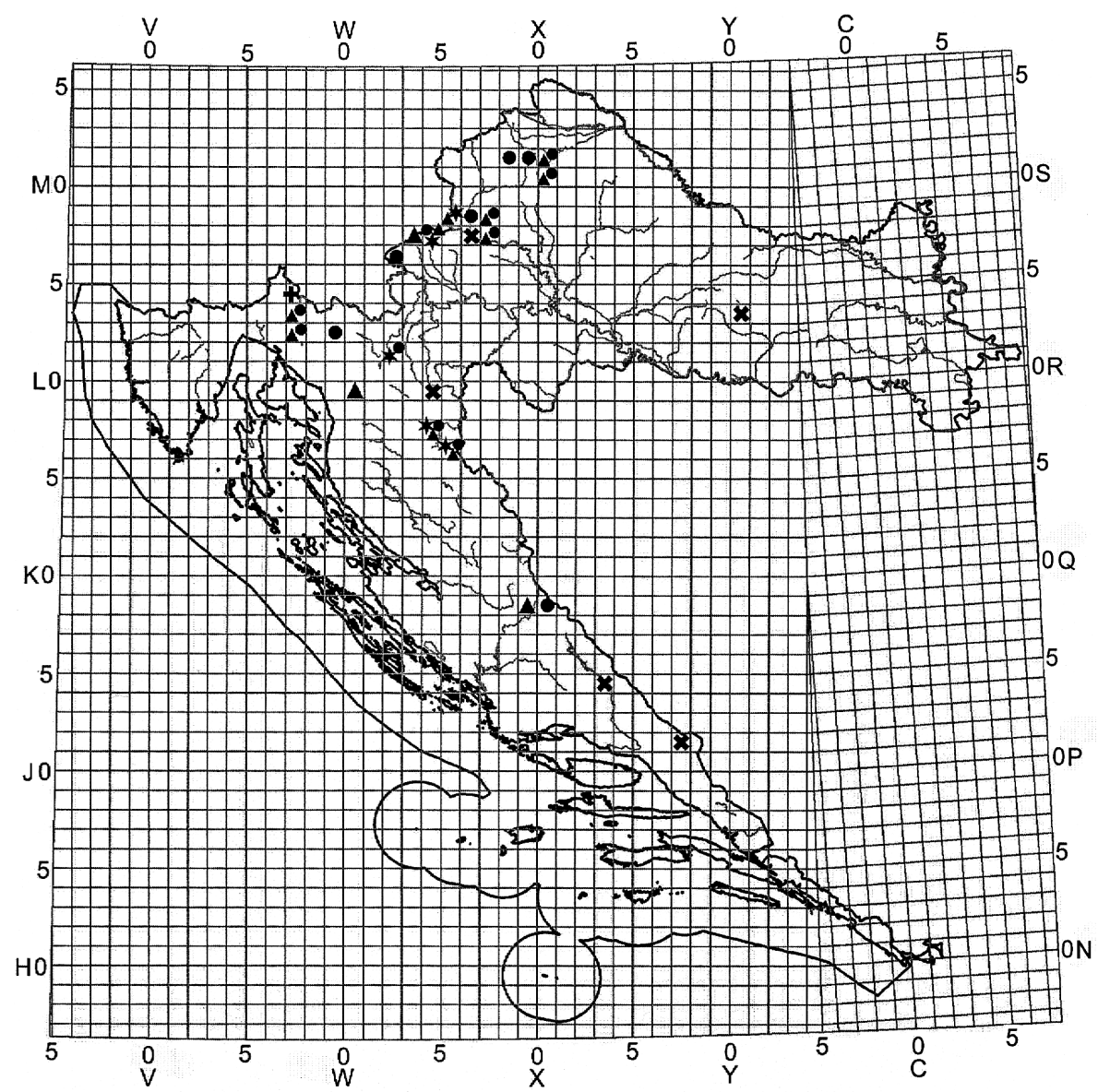

\section{$\Delta=$ B. parasita, $\bullet=B$. pentodonta, $*=B$. hexodonta $\boldsymbol{\Psi}=$ not identified, $\mathbf{x}=$ not found}

Fig. 2. The distribution of different branchiobdellidan species on Austropotamobius torrentium in Croatia.

asita, although in their observations $B$. parasita was slightly more abundant on $A$. torrentium than $B$. pentodonta. However, B. parasita has neither been found on the native A. pallipes distributed in the Adriatic Sea drainage, nor on A. leptodactylus or the North American O. limosus.

While $B$. parasita is much larger and distinctly different from B. pentodonta, B. italica and B. balcanica, these latter three species share many morphological similarities to the extent that Pop (1965) and Karaman (1967) assigned them to a "pentodonta" group or complex. Karaman (1967) went a step further and hypothesized a possible speciation pattern going from $B$. italica to $B$. pentodonta, and finally to B. balcanica. Actually, the only character that reliably separates $B$. italica from $B$. pentodonta is the ratio of the spermathecal duct to the bulb length. This criterion is not always easy to observe in preparations, but it proved to be consistent in the populations studied by Gelder et al. (1994). Although $B$. kozarovi shares a number of similarities with the "pentodonta" group, it is sufficiently different to warrant species status and not be included in the "pentodonta" complex (Subchev 1978).

Karaman (1967) speculated that B. italica prefers association with A. pallipes (or A. italicus as he called it). He also discussed the possibility that $B$. pentodonta had been spread on A. torrentium as a psychrophilic species which invaded northern Europe, together with A. asta- 


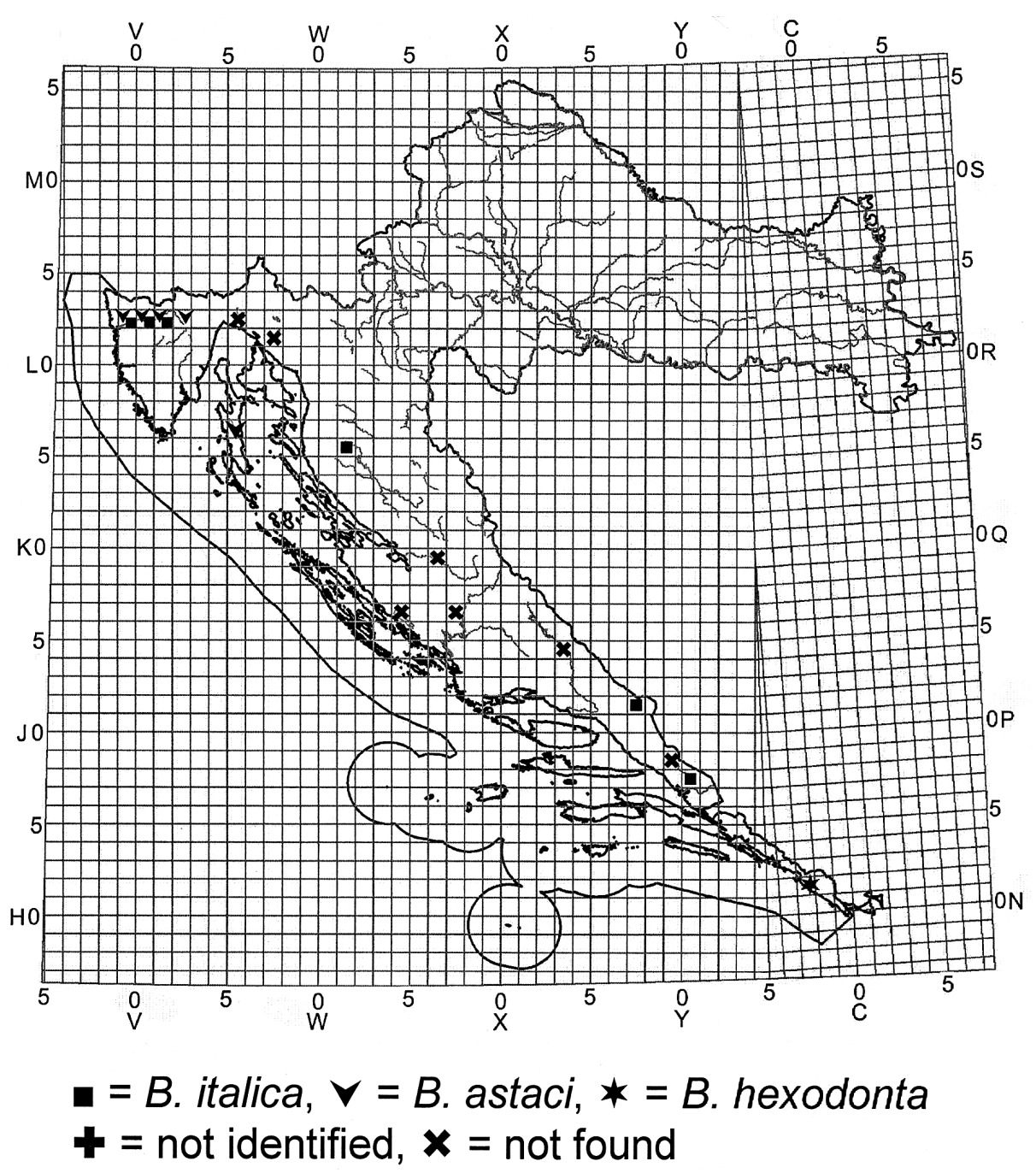

Fig. 3. The distribution of different branchiobdellidan species on Austropotamobius pallipes in Croatia.

cus, in the last postglacial period. According to Karaman (1970) B. balcanica is a thermophilic species associated more with $A$. astacus than with other crayfish species. This would explain why $B$. pentodonta is usually found at higher altitudes than $B$. balcanica and our results support this hypothesis. We found B. italica only on A. pallipes, while $B$. pentodonta was the most frequently observed branchiobdellidan species on A. torrentium, and B. balcanica almost exclusively on $A$. astacus, and in relatively high numbers (Table 2). Results presented by Subchev and Stanimirova (1997) for Bulgaria are in agreement with our observations.

One of the reasons for more published data on B. parasita, B. italica, B. pentodonta and B. balcanica than on other branchiobdellidan species in Europe is that these taxa inhabit the surface of the crayfish (none gill chamber-dwelling), while B. astaci and B. hexodonta both live in the gill chambers and are not so easily observed. Probably for this reason, Karaman (1967) was convinced that B. astaci did not occur in the territory covered by the former Yugoslavia in spite of Moszyńsky (1938) finding specimens of this species in Kosovska Mitrovica (Serbia).

Our data show the presence of B. astacion $25 \%$ of all of the examined populations of A.pallipes. This association is limited to the western, karstic, part of Croatia (Istra) which drains into the Adriatic Sea. This karstic area extends into adjacent Slovenia and Italy where, in the Tri- 
Table 2. The total percentage of branchiobdellid species on examined crayfish populations.

\begin{tabular}{|c|c|c|c|c|c|c|}
\hline $\mathrm{Crayfish}_{\text {Branchiobdellid }}^{\text {Brat }}$ & B. parasita & B. pentodonta & B. balcanica & B. astaci & B. hexodonta & B. italica \\
\hline A. astacus & $47.4 \%$ & $15.8 \%$ & $21.1 \%$ & $5.3 \%$ & $5.3 \%$ & - \\
\hline A. leptodactylus & - & - & - & - & - & - \\
\hline A. pallipes & - & - & - & $26.3 \%$ & $5.3 \%$ & $36.8 \%$ \\
\hline A. torrentium & $46.9 \%$ & $53.1 \%$ & - & - & $6.3 \%$ & - \\
\hline O. limosus & - & - & - & - & - & - \\
\hline
\end{tabular}

Table 3. Number of locations where coexistence of two or more species of Branchiobdella were recorded within the same crayfish population.

\begin{tabular}{|c|c|c|c|}
\hline Branchiobdellids & A. astacus & A. torrentium & A. pallipes \\
\hline B. parasita $+B$. pentodonta & 2 & 6 & \\
\hline$B$. parasita $+B$. pentodonta $+B$. hexodonta & & 2 & \\
\hline B. parasita $+B$. balcanica & 1 & & \\
\hline B. parasita $+B$. balcanica $+B$. hexodonta & 1 & & \\
\hline B. parasita $+B$. hexodonta & & 1 & \\
\hline B. pentodonta + B. balcanica & 1 & & \\
\hline B. pentodonta $+B$. hexodonta & & 1 & \\
\hline B. italica + B. astaci & & & 3 \\
\hline
\end{tabular}

este area, Gelder et al. (1994) obtained specimens of $B$. astaci. Gelder and his colleagues speculated that this species was introduced into the area from the central European drainage at some time in the past. This suggestion is supported in part by collections made in adjacent Slovenia from the headwaters of the Sava River basin (Gelder et al. 1994) where B. astaci was found on A. astacus. The absence of $B$. astaci in other parts of Croatia and, according to Karaman (1967), from Bosnia and Herzegovina, Serbia and Macedonia is somewhat puzzling since it has been observed in Slovenia (Gelder et al. 1994), Hungary and Bulgaria (Subchev 1984, Subchev \& Stanimirova 1997), where it was associated with A. astacus or A. torrentium.

Branchiobdellidan species inhabiting the outer surface of crayfish can sometimes be found sympatrically on the same individual host, but this has never been recorded for the two gill-dwelling species, B. astaci and $B$. hexodonta. Branchiobdella hexodonta is present on populations of A. astacus, A. pallipes and A. torrentium in about the same frequency $(5.0,6.3$, and $3.0 \%$, respectively). These frequencies are modest compared to those reported by Subchev and Stanimirova (1997) where the frequencies were much higher:A. astacus (13.3\%) and $A$. torrentium (60\%). The role of B. astaci and B. hexodonta damaging the host's gills is supported by circumstantial observations but awaits general definitive experimental data.

Coexistence of two or more species of branchiobdellidans on crayfish at the same location presents an interesting and, so far, unexplained ecological phenomenon (Gelder et al. 1994, 1999). In our research we have observed different species groupings with the most frequent being a parasita-pentodonta combination most often found on populations of $A$. torrentium and to some lesser extent, on populations of A. astacus (Table 3). Branchiobdella parasita seems to be a very tolerant species as it can be found with B. balcanica (on A. astacus) and B. hexodonta (on A. astacus and A. torrentium). Combinations of pentodonta-balcanica (on A. astacus) and italica-astaci (onA.pallipes) were also observed. On rare occasions we also found three different species at the same location where $B$. hexodonta had "joined" the combination of parasita-pentodonta or parasita-balcanica. The microhabitat separation of the gill-dwelling species and those externally would not cause any conflict or com- 
petition. These findings are similar to those of Subchev and Stanimirova (1997) considering the difference in species diversity of Croatia and Bulgaria, but, branchiobdellidan-free populations were found to be slightly higher in Croatia than Bulgaria. Our study used variable numbers of crayfish from a population and sometimes the sample size was small. While these data have provided some useful comparisons, it is possible that the results may have been influenced by the number of crayfish available.

Orconectes limosus is a well-known host of branchiobdellidans in North America (Gelder 2004), but so far we have not found any branchiobdellidans, allochtonous or autochtonous, on this invasive crayfish species in Croatia, and neither did Oberkofler et al. (2002) in South Tyrol (Northern Italy). However, Vogt (1999) reported $B$. parasita and $B$. pentodonta on both $A$. torrentium and $O$. limosus living in the Steinbeck Creek, Hesse, Germany, indicating that the imported species is an acceptable host for the native branchiobdellidans. A similar situation was reported in northern Italy (Gelder et al. 1999) where $B$. italica and B. parasita on the local population of A. pallipes had adopted introduced North American Procambarus clarkii (Girard, 1852) as hosts. These specimens of P. clarkii carried Cambarincola mesochoreus Hoffman, 1963 and provided the only report of this imported branchiobdellidan species in Europe at this time. Of even greater concern is the increasing spread of the nonnative, Pacifastacus leniusculus (Dana, 1852) across Western Europe (Lowery \& Holdich 1988, Lewis 2002) through Slovenia (Gelder 2004, Machino pers. comm.) and towards Croatia. This crayfish invariably carries the branchiobdellidan, Xironogiton victoriensis Gelder and Hall, 1990, which has been reported from Sweden (Franzén 1962), Spain (Gelder 1999), Finland (Kirjavainen \& Westman 1999), Northern Italy (Quaglio et al. 2002, Gelder 2004), and is almost certainly to be found wherever the crayfish has been introduced. The destruction of native crayfish populations by the imported species through competition and pathogens presents a serious and growing concern (Holdich et al. 1999). This will only become worse as the introduction and spread of nonnative North American crayfishes in Europe continues through largely unregulated commercial projects and the pet industry.

The results of our base-line study have provided a preliminary picture of branchiobdellidans' presence on the crayfishes and their distribution within the freshwater habitats in Croatia. As far as is known at this time, North American crayfishes, apart from $O$. limosus, and their pathogens have not entered Croatian waters. Constant monitoring and further research are needed to ensure that the native populations of crayfish and their ectosymbionts in Croatia are not destroyed.

\section{References}

Brinkhurst R.O. \& Gelder S.R. 2001. - Annelida: Oligochaeta, including Branchiobdellidae. Pages 456-463 in Ecology and Classification of North American Freshwater Invertebrates 2nd ed. Thorpe J.H. \& Covich A. (eds). Academic Press, New York.

Evans L.H. \& Edgerton B.F. 2002. - Pathogens, parasites and commensals. Pages 377-438 in Biology of freshwater crayfish. Holdich D.M. (ed). Blackwell Science, Oxford.

Franzén Å. 1962. - Notes on the morphology and histology of Xironogiton instabilia (Moore 1893) (Fam. Branchiobdellidae) with special reference to the muscle cells. Zool. Bidr. Uppsala, 35, 369-383.

Gelder S.R. 1996. - A review of the taxonomic nomenclature and a checklist of the species of the Branchiobdellae (Annelida: Clitellata). Proc. Biol. Soc. Wash., 109, 653-663.

Gelder S.R. 1999. - Zoogeography of branchiobdellidans (Annelida) and temnocephalidans (Platyhelminthes) ectosymbiotic on freshwater crustaceans, and their reactions to one another in vitro. Hydrobiologia, 406, 21-31

Gelder S.R. 2004. - Endemic ectosymbiotic branchiobdellidans (Annelida: Clitellata) reported on three "export" species of North American crayfish (Crustacea: Astacoidea). Freshwat. Crayfish, 14, 221-227.

Gelder S.R. \& Ohtaka A. 2002. - A Review of the Oriental Branchiobdellidans (Annelida: Clitellata) with Reference to the Rediscovered Slide Collection of Prof. Hideji Yamaguchi. Species Divers., 7, 333-344.

Gelder S.R., Delmastro G.B. \& Ferraguti M. 1994. - A report on branchiobdellidans (Annelida: Clitellata) and a taxonomic key to the species in northern Italy, including the first record of Cambarincola mesochoreus on the introduced American red swamp crayfish. Boll. Zool., 61, 179-183.

Gelder S.R., Delmastro G.B. \& Rayburn J.N. 1999. - Distribution of native and exotic branchiobdellidans (Annelida: Clitellata) on their respective crayfish hosts in northern Italy, with the first record of native Branchiobdella species on an exotic North American crayfish. J. Limnol., 58, 20-24.

Georgévitch J. 1957. - Contribution à la connaissance des aelosomatidés de la Yugoslavie. Bull. Acad. Serbe Sci. Cl. Sci. Math. Nat., 18, 93-95.

Halgoš J. 1972. - Beitrag zur kenntnis der Ektoparasitischen würmer der ordnung Branchiobdellida in der Slowakei (Annelida: Clitellata). Ac. Rer. Natur. Mus. Nat. Slov., Bratislava, 18, 63-69.

Holdich D.M., Ackefors H., Gherardi F., Rogers W.D. \& Skurdal J. 1999. - Native and alien crayfish in Europe: Some conclusions. Pages 281-292 in Crayfish in Europea as alien species. How to make the best of a bad situation? Gherardi F. \& Holdich D.M. (eds). AA Balkema, Brookfield.

Karaman S.M. 1967. - Branchiobdelldae Jugoslavije (Annelida: Clitellata). Bul. Pun. Shken. Fak. Fil. Prisht., 4, 39-63.

Karaman S.M. 1970. - Beitrag zur Kenntnis der europaischen Branchiobdelliden (Clitellata, Branchiobdellidea). Int. Rev. Hydrobiol., 55, 325-333.

Kirjavainen J. \& Westman K. 1999. - Natural history and development of the introduced signal crayfish, Pacifastacus leniusculus, in a small, isolated Finnish lake, from 1968 to 1993. Aquat. Living Resour., 12, 387-401.

Lewis S.D. 2002. - Pacifastacus. Pages 511-541 in Biology of freshwater crayfish. Holdich D.M. (ed). Blackwell science, Oxford. 
Lowery R.S. \& Holdich D.M. 1988. - Pacifastacus leniusculus in North America and Europe, with details of the distribution of introduced and native crayfish species in Europe. Pages 283-308 in Freshwater Crayfish: Biology, Management and Exploitation. Holdich D.M. \& Lowery R.S. (eds). Croom Helm, London.

Maguire I. \& Gottstein-Matočec S. 2004. - The distribution pattern of freshwater crayfish in Croatia. Crustaceana, 77, 25-47.

Maguire I., Klobučar G., Faller M., Machino Y., Kučinić M. \& Zužul M. 2006. - Updates on the distribution of the white-clawed and the narrow-clawed crayfish in Croatia. Crayfish News, 28, 45 .

Moszyński A. 1938. - Oligochetes parasites de l’ecrevisse (Potamobius astacus L.) de la Yougoslavie. Bull. Soc. Sci. Skoplje, 18, 69-75.

Nesemann H. 1994. - Die Krebsegel im Gebiet der Oberen Donau (Östereich, Deutschland) mit Bestimmungsschlussel zu den europäischen Arten (Clitellata, Branchiobdellida). Lauterbornia $H, 19,79-93$.

Oberkofler B., Quaglio F., Füreder L., Fioravanti M.L., Giannetto S., Morolli C. \& Minelli G. 2002. - Species of Branchiobdellidae (Annelida) on freshwater crayfish in South Tyrol (Northern Italy). Bull. Fr. Pêche Piscic., 367, 777-784.

Pop V. 1965. - Systematischen Revision der europäischen Branchiobdelliden (Oligochaeta). Zool. Jahrb. Abt. Syst. Oekol. Geogr. Tiere, 92, 219-238.
Quaglio F., Fioravanti M.L., Gelder S.R., Giannetto S., Trentini M., Nobile L., Maxia M. \& Morolli C. 2002. - Infestation of the branchiobdellidan, Xironogiton victoriensis (Annelida, Clitellata), on the signal crayfish (Pacifastacus leniusculus) from Auenbachl Creek, Alto Adige/Süd Tyrol, Italy. Freshwater Crayfish, 13, 274-279.

Subchev M.A. 1978. - A new branchiobdellid - Branchiobdella kozarovi sp.n. (Oligochaeta, Branchiobdellidae) from Bulgaria. Acta Zool. Bulg., 9, 78-80.

Subchev M.A. 1984. - On Hungarian Branchiobdellids (Oligochaeta: Branchiobdellidae). Misc. Zool. Hungarica, 2, 4750 .

Subchev M.A. \& Stanimirova L.S. 1997. - Distribution of freshwater crayfishes (Crustacea: Astacidae) and the epibionts of the genus Branchiobdella (Annelida: Branchiobdellae), Hystricosoma chappuisi Michealsen, 1926 (Annelida, Oligochaeta) and Nitrocrella divaricata (Crustacea: Copepoda) in Bulgaria. Hist. Nat. Bulg., 9, 5-18.

Vogt G. 1999. - Disease of European freshwater crayfish, with particular emphasis on interspecific transmission of pathogens. Pages 87-103 in Crayfish in Europea as alien species. How to make the best of a bad situation? Gherardi F. \& Holdich D.M. (eds). AA Balkema, Brookfield. 